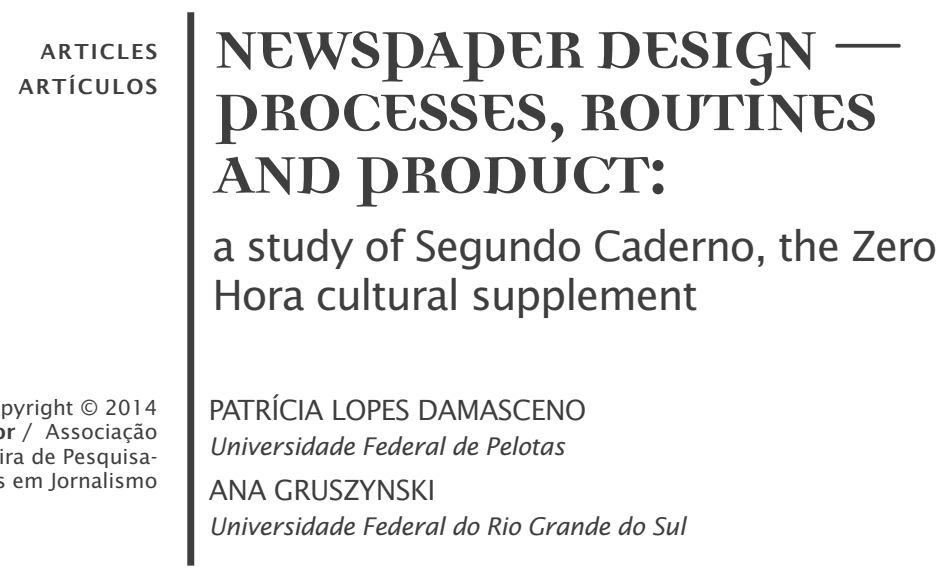

\begin{abstract}
The article discusses the graphic design of Segundo Caderno supplement from the newspaper Zero Hora (ZH). The study identifies and analyses witch graphical elements e what compositional strategies are used by the periodic, verifying how these area articulated with the editorial process and the values of the journalistic field. The methodological procedures utilized were bibliographical research; qualitative and quantitative evaluation of a corpus composed by 24 editions of the months of June, August, September and October of 201 1; observation of the productive routines; and non-structured interviews with five professionals of this supplement. The results showed that journalism possesses a strong e consolidated work culture, and that its constraints guide the design practice in this context. It was also observed that the ignorance of the reader's profile by the journalists, the mismatch between the possibility of advanced planning in virtue of the connection with the events agenda and the restricted use of visual resources, highlighting by a significant number of released photos.
\end{abstract}

Keywords: Newspaper design. Editorial design. Cultural journalism. Segundo Caderno. Zero Hora.

\title{
DESIGN DE JORNAIS - PROCESSOS, ROTINAS E PRODUTO: um estudo do Segundo Caderno, suplemento cultural de Zero Hora
}

RESUMO - O artigo trata do projeto gráfico do suplemento de cultura diário Segundo Caderno do jornal Zero Hora (ZH). O estudo identifica e analisa quais elementos gráficos e que estratégias compositivas são utilizadas pela publicação, verificando como eles se articulavam com os processos editoriais e com os valores do campo jornalístico. Os procedimentos metodológicos adotados foram a pesquisa bibliográfica; a avaliação quantitativa e qualitativa de um corpus composto por 24 edições de julho, agosto, setembro e outubro de 2011 ; a observação das rotinas produtivas; e entrevistas não estruturadas com cinco profissionais dessa editoria. Os resultados mostraram que o jornalismo possui uma cultura de trabalho muito forte e consolidada, e que suas condicionantes guiam a prática do design nesse contexto. Observouse ainda o desconhecimento do perfil de leitores por parte dos profissionais da redação, o descompasso entre a possibilidade de planejamento antecipado do conteúdo em virtude da ligação com a agenda de eventos e o uso restrito de recursos visuais, destacando-se o número significativo de fotos de divulgação.

Palavras-chave: Design de jornais. Design editorial. Jornalismo cultural. Segundo Caderno. Zero Hora. 


\section{DISEÑO DE PERIÓDICOS - PROCESOS, RUTINAS Y PRODUCTO: un estúdio de Segundo Caderno, suplemento de cultura de Zero Hora}

RESUMEN - Este artículo se ocupa del proyecto gráfico Segundo Caderno, suplemento diario de cultura del periódico Zero Hora (ZH). El estudio identifica y analiza los elementos gráficos y las estrategias compositivas utilizadas por la publicación, verificando cómo se articulan con los procesos editoriales y con los valores del campo periodístico. Los procedimientos metodológicos adoptados fueron: la investigación bibliográfica; la evaluación cuantitativa y cualitativa de un corpus compuesto por veinticuatro ediciones de julio, agosto, septiembre y octubre de 2011 ; la observación de las rutinas productivas; y entrevistas no estructuradas con cinco profesionales del suplemento mencionado. Los resultados mostraron que el periodismo tiene una cultura de trabajo consolidada y que sus condicionantes guían la práctica del diseño en este contexto. Asimismo, se ha observado el desconocimiento del perfil de los lectores por parte de los profesionales de la redacción y la discordancia entre la posibilidad de la planificación anticipada del contenido en virtud de la conexión con la agenda de eventos y el uso limitado de recursos visuales, destacándose el número significativo de fotos de divulgación.

Palabras clave: Diseño de periódicos. Diseño editorial. Periodismo cultural. Segundo Caderno. Zero Hora.

\section{INTRODUCTION}

The graphic form of a printed newspaper is part of the communication pact established between a publication and its readers. Gäde (2002) believes that the readers' trust in the content of a periodical is related to the way the original and authentic visual aspect is presented to them, how it is perceived: taking into consideration the texture and quality of the paper, the quality of the printing, the way in which elements are arranged in the page and so on. The recurrent visual structure makes a periodical recognizable, even though the content changes completely from on day to another. Design is strategic to guide the readers' eyes through the page, since the disposition of the visual elements can describe different reading movements (GRUSZYNSKI, 2011). The graphic planning acts as a mediator that gives a form to the periodical, thus structuring the organization and the hierarchy of the informative elements according to the editors' criteria.

This paper discusses the field of editorial production, focusing on the visual presentation of the printed newspaper, and, more narrowly, on a systematic analysis of the visual disposition in the cultural supplement ${ }^{1}$. In recent years, design has become an important issue for printed newspapers due to the decrease in sales in the sector and the contemporary media configuration, which has been marked by digital technologies. Since 2008 , several graphic changes have been made by 
Brazil's main newspapers ${ }^{2}$. In this context, some periodicals such as Folha de São Paulo chose to use this phenomenon as an advertisement strategy (GRUSZYNSKI, 2012). In other instances, great investments were made in hiring companies that specialize in design to develop new visual projects, which highlights the importance of the graphic elements among all the changes being made ${ }^{3}$.

This attention bestowed on graphic design retraces the experiences of the 1950s, when some of the main Brazilian newspapers focused on the visual potential of their product. Even though it is a different context, it is possible to detect the trajectory of Jornal do Brasil (JB), which established a new graphic dynamics with its cultural supplement, Caderno $B$. This publication was one of the main exponents both in editorial project and graphic design, becoming a reference not only for cultural supplements, but also for the field of print journalism in Brazil. Regarding the graphic design, we highlight the fact that a newspaper can be transformed by having its aesthetic proposal as its flagship and finding, in the cultural supplement, the ideal environment for experimenting. According to Golin and Cardoso (2010, p. 9), one of the striking characteristics of this type of journalistic approach is in the visual appearance, where "historically, this segment uses the graphic design as a form of discursive differentiation."

On the other hand, considering the crisis in the sector, the newspaper really began to focus on "becoming visually more attractive" (DEJAVITE, 2008, p. 1) besides offering information that matched the readership's new preferences. These tactics were an attempt to increase customer loyalty and even enhance sales and subscriptions. Thus the segment dedicated to culture can once more be identified as strategic, as it becomes an important entry point for the younger readership ${ }^{4}$. According to Piza (2009), the culture sections are among the most read and they are often responsible for bringing together and maintaining the readership: "the culture section has always been a powerful identity link between the reader and the publication" (PIZA, 2009, p. 64). To that author, the nature of the subjects of the culture section is inviting, presenting activities that are usually pleasurable.

In agreement with the brief panorama presented, in 2009, Rio Grande do Sul's (RS) prestigious daily newspaper Zero Hora launched an edition commemorating its 45th year, marked by a new visual design in its graphic project, among other aspects. The publication has the biggest paid circulation in Rio Grande do Sul state (RS) and occupies sixth place in Brazil. According to data from the Instituto Verificador de Circulação 
[Circulation Verifying Institute] (IVC), the average daily issue reached 190,761 in August of $2011^{5}$. Zero Hora also leads in readership: according Ibope $^{6}$ data for October 2010, the newspaper has around 1.7 million readers. Its dominant position in RS is also due to the fact that it belongs to the greatest communication conglomerate of the aforementioned state, the Rede Brasil Sul de Comunicação (RBS) (FONSECA, 2008). Among its 25 sections, the daily supplement dedicated to the coverage of cultural events is the Segundo Caderno, published from Monday to Saturday. It is among the most read parts of the newspaper ${ }^{7}$, reaching third place with 401,000 readers $^{8}$ and surpassed only by the weekly TV+Show $(424,000)$ and Culture $(414,000)$, both produced by the same editorial board - a fact that proves the readership's interest in the cultural segment.

Our study identified and analyzed the graphic elements and compositional strategies used in Segundo Caderno, observing how they relate to the editorial processes and journalistic values, in order to understand the specificities of the graphic design of a cultural segment. The methodological procedures consisted of bibliographical research; the quantitative and qualitative evaluation of a corpus comprised of 24 issues in July, August, September, and October 2011; the observation of the production routines; and informal interviews with five members of the editorial staff. For our corpus we selected one week of publication a month for four months in which we scheduled the last week of analysis of the issues to coincide with our in loco observations.

The categories of graphic design were elaborated based on bibliographic research, especially on authors dedicated to the study of visual phenomena (ARNHEIM, 2005; DONDIS, 2007; GOMES FILHO, 2004; LUPTON and PHILLIPS, 2008) and newspaper design (FROST, 2003; GARCIA, 1987; LAREQUI, 1994; LOCKWOOD, 1992; ZAPPATERRA, 2007). Singular elements were used to make up a table showing the quantitative analysis. The strategies of inter-element articulation (for which the quantitative data gathered served as reference) and their connection to the informative content were analyzed by means of a quantitative assessment.

Our initial goal was not to only analyze the final product, but also to discuss which processes were involved in the daily activities of the newspaper to determine what goes on the page, what does not, and, especially, the way in which this content is offered to the reader, with the aim of delineating how the editing process is related to what is actually published. 


\section{THE GRAPHIC DESIGN OF SEGUNDO CADERNO}

$\mathrm{ZH}$ is a tabloid newspaper, with dimensions of $28.3 \times 38 \mathrm{~cm}$, with a live area of $26 \times 35 \mathrm{~cm}$ divided in a five-column layout. The pagination exploits variations in the width of the columns throughout the pages and issues, creating different possibilities for the base grid. In a total of eight pages, Segundo Caderno follows the tradition of offering a structure of sections organized by pages, which is maintained throughout the week with some alterations on specific days. The structure of the supplement is:

Cover (Image 1) - The cover generally focuses on only one subject which may or may not be continued on the inside pages, and with a dominant image. In the layout, the folio has the brand of the newspaper, the city, the day of the week, and the date. Under this section, there is the flag of the supplement and, sometimes, on the left of the flag, there are jump lines to stories inside the supplement. Below the flag there is a colored bar with the Segundo Caderno website and the name and contact information of the editor and the person responsible for the layout design. Regarding colors, the decision is made based on the predominant color of the main image. Other recurring elements are the title in a combination of regular fonts and fonts in bold, a vertical bar at the beginning of the support cutoff rule, the signature of the journalist at the beginning of the story, the lead in bold, and the use of initials. When necessary, boxes with additional information or highlights of the text are added, being separated by cutoff rules or a background in a different color.

Image 1 Covers, 03/03/11;02/23/11;02/22/11

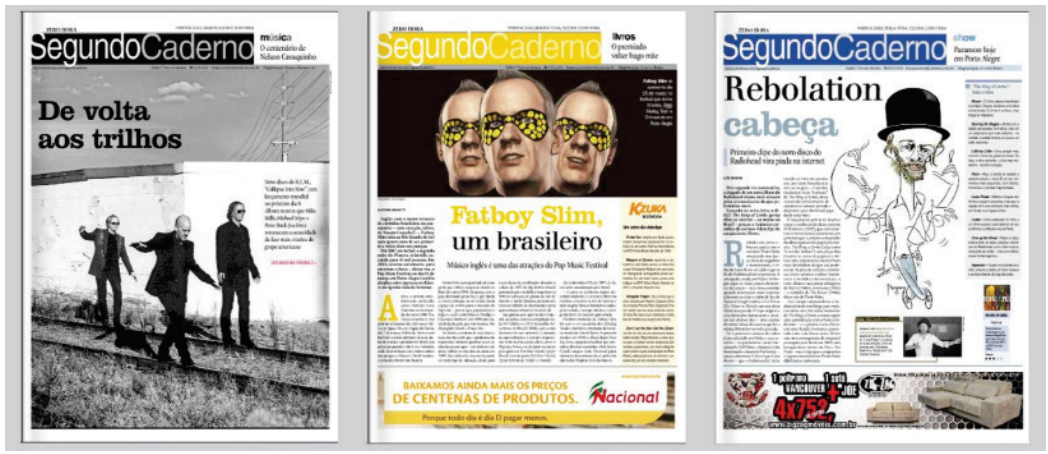

Page 2, social column (Image 2) - The mosaic of notes, briefs and cutlines. The content layout uses smaller headlines than those 
used throughout the rest of the supplement, initial caps, and boxes for highlighted contents. The texts are aligned to the left margin and are also different from the other pages in the supplement. There are font variations of serif and sans-serif, and small caps, among other resources. There is no standard pattern for the number of columns or the size of the pictures. We can even find pictures of cut-out objects against the background. The heading, in this case, has the name of the column with the picture and name of the columnist.

Image 2 Pages $2,12 / 05 / 11 ; 11 / 29 / 11 ; 11 / 22 / 11$

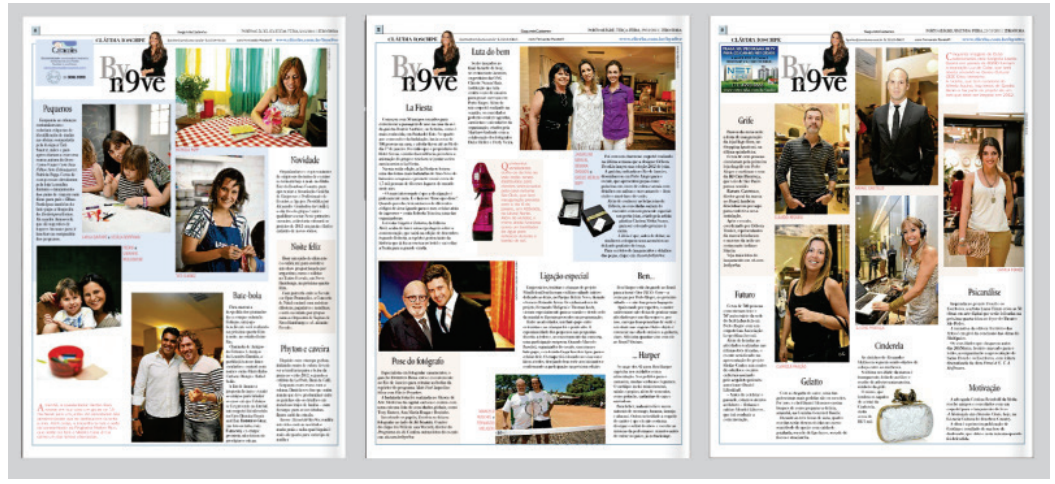

Page 3 (Image 3) - Space comprised of many themes where we find the biggest advertisements - or a bigger number of advertisements, and fixed columns on Mondays and Tuesdays. Because of these factors, the editorial space is reduced, generally giving prominence to a story that is indicated by one or more header. The visual disposition follows the model of the cover.

Image 3 Pages $3,11 / 29 / 11 ; 11 / 21 / 11 ; 03 / 07 / 11$

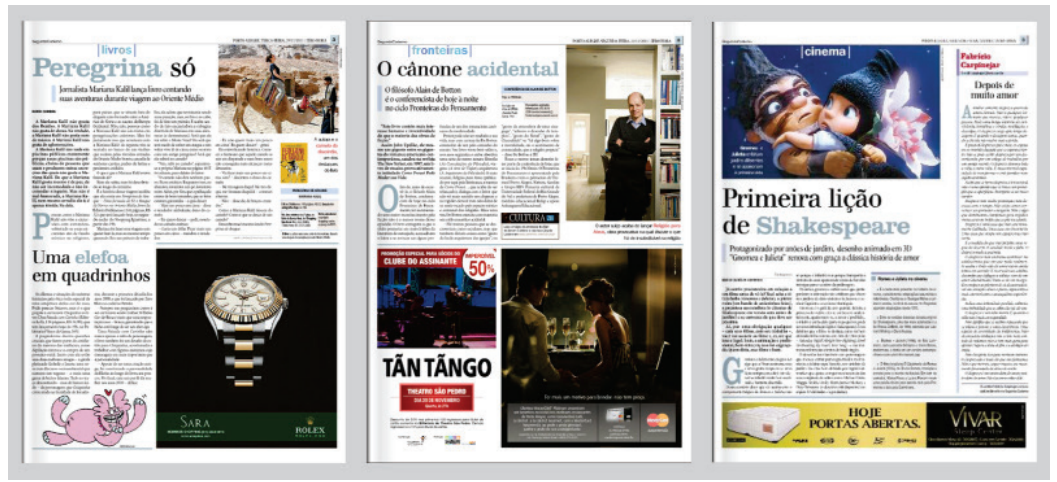


Middle pages, 4 and 5 (Image 4) - One of the main differences of these pages lies in the possibility of planning the double page. This is possible because there are no internal margins, thus favoring the sequential flow throughout the page. There is usually more than one picture on the page, and one of them is always given prominence. When there is more than one story, the biggest picture corresponds to the most relevant subject. It is worth noting that in these layouts the even-numbered page (the one of the left) is normally the one holding the main story. Another evident characteristic is that the header is what divides the themes on every day of the week, except Saturdays. The themes and their corresponding days are: Mondays interview, Tuesdays music albums, Wednesdays books, Thursdays cinema, Fridays premieres. However, it can be stated that this regularity is sometimes broken. In addition, the middle pages have a column on Saturdays.

Image 4 Pages 4 and 5 (middle), 03/05/11;02/21/11

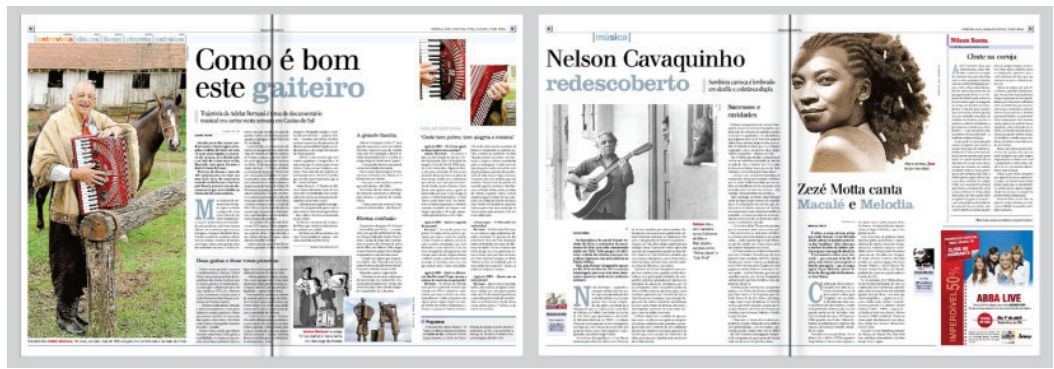

Page 6 (Image 5) - Similar to what happens on page three, on this page there is also a variety of themes. The visual presentation follows the model of the supplement, with the same visual set-up and patterns. The main difference is in the editorial structure with the presence of daily columns, except on Fridays. On this day of the week, there is a recurring structure on the theme of cinema, corresponding to the header DVD and Releases and, at times, TOP10 with the most rented movies. In this same manner, on Saturdays, in addition to the daily column, there is a section for children, Clubinho, and one for adolescents, Kzuca. 
Image 5 Pages $6,11 / 19 / 11 ; 11 / 22 / 11 ; 11 / 11 / 11$

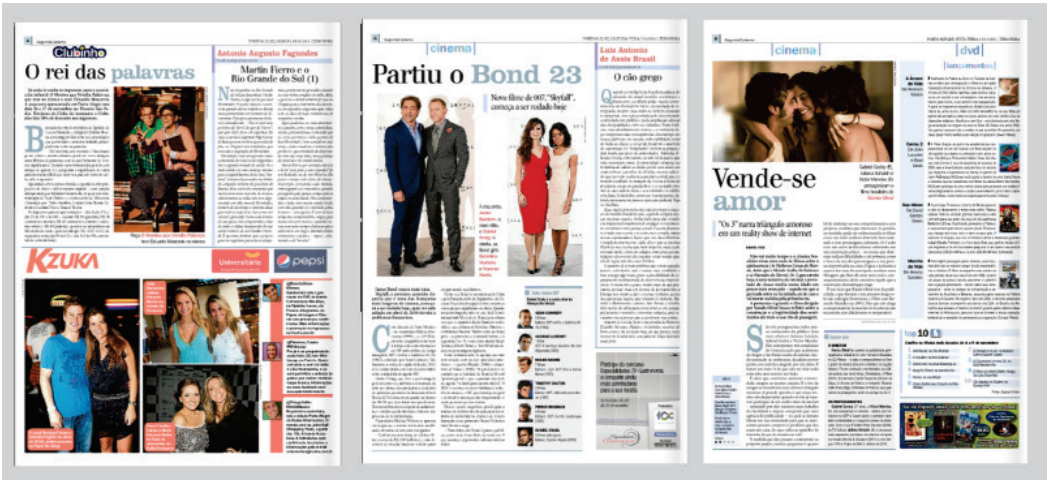

Page 7 (Image 6) - This is the section with the most structural regularity, both editorially and visually, where we find comic strips, crossword puzzles, and the horoscope section. The color pattern follows the shades of blue of the segment, as well as the aspect of the headers.

Image 6 Page 7, 12/05/11

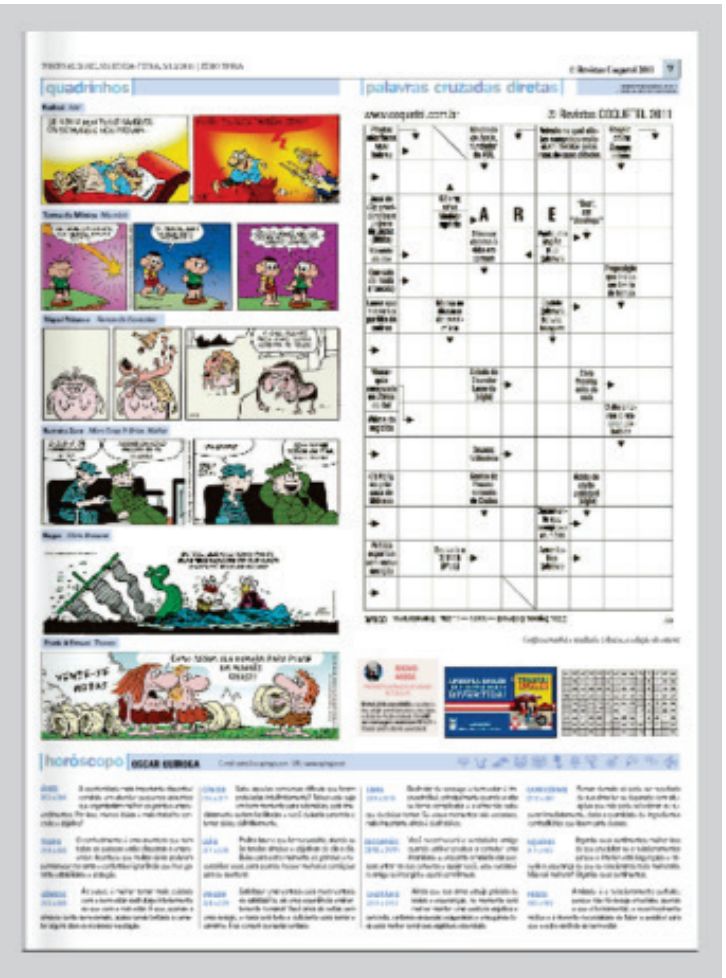


Back cover (Image 7) - Composed of pictures and notes, the set-up of this page is in agreement with page two in many aspects. The content is organized by smaller headlines in relation to the other pages of the supplement, with the presence of initial caps and boxes. The note present at the top of the page receives most prominence. There is a box containing a quote from a personality, highlighted with colors in the background and quotation marks. Illustrations can be found more often.

Image 7 Back covers, 11/30/11;11/19/11;11/25/11

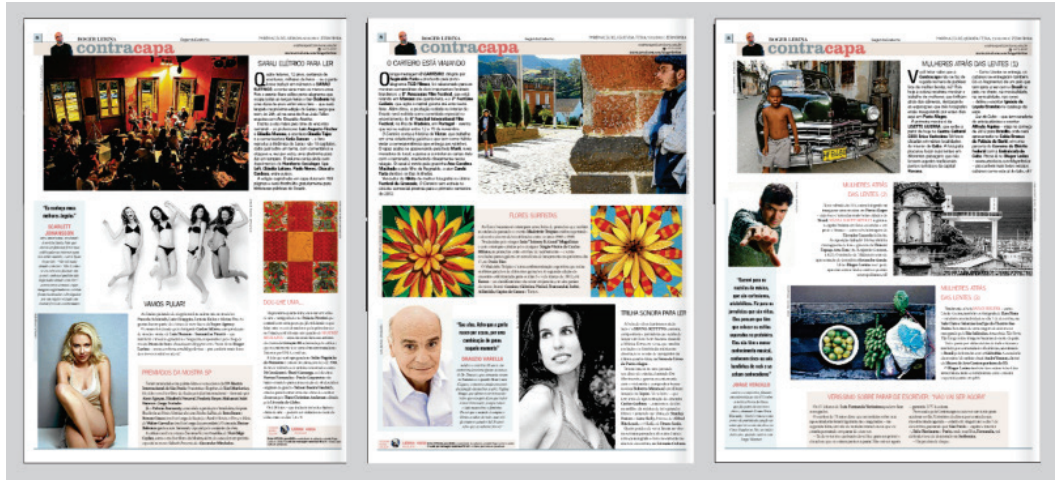

Broadly speaking, it can be seen that there is a pattern throughout the pages of the supplement. The color palette employed follows the same style of the newspaper, with shades of blue as well as the use of red for details. Other elements that make up the model of the supplement are: headlines, that have a combination of words in bold and in the regular manner; the beginning of a vertical bar in the support cutoff rule; the byline at the beginning of the story; the lead highlighted in bold; the use of initial caps; the style of the image caption, as well as the style of the headers, boxes, cutoff rules, and other components.

\section{PROCESSES AND PRACTICES THAT GUIDE THE EDITORIAL DESIGN}

The methodological procedures adopted different perspectives that guided observations of the editorial process and production routines of Segundo Caderno and, consequently, helped to reveal the specificities of the design developed for the cultural segment of the media vehicle studied here. On a theoretical level, we infer that both journalistic and design practices aim to kindle interest in reading. The visual presentation and the information itself create 
a unit in which resources from different sources converge to achieve that goal. As a product of the journalistic practice, the news piece is its representative element; it corresponds to the graphic design in several ways. In both cases, the basic assumption is that they use their respective techniques as a way of selecting, valuing, and establishing a hierarchy of the contents. In journalism, the process of assessing facts obeys certain parameters - newsworthiness and newsvalue criteria (WOLF, 1995) - which govern the selection of what is considered more important to cover. In design, the joining of graphic elements aims to establish a connection to those values of the news piece content. The routines thus establish a flow of activities that aim at minimizing the subjectivity of the process and making it quicker, since decisions are made in a context in which deadlines are tight and where hesitation and doubt are not welcome.

When design harmonizes with journalism, we see graphic forms that aim at being the visual expression of the content. On the other hand, there is a plurality of ways to express it that are directly connected to the nature of the many segments of journalism. Cultural journalism, even though it is guided by the general ideas of the field, is a distinct method of producing knowledge and a result of the environment in which it is produced, distributed, and consumed.

Regarding the model used in the Segundo Caderno and other supplements of the same sort, the one in question here was consolidated between the mid 1980s and early 1990s, with newspapers creating individual sections to reach a readership interested in specific matters, according to marketing strategies of the time. Since then, the organization of content has aimed to bring contents together in groups of pages both at the editorial and the graphic level. This strategy is still used today, according to Garcia (1987), who calls this division packaging, and Larequi (1994), who calls it division by theme.

Nowadays, the strategy of dividing the newspaper in sections has as a reference the preferences of the local publicity market and of the newspaper subscribers, as well as the behavior of the newspaper staff. Luiz Adolfo Lino de Souza (2011), art editor of ZH, explained that the periodical has 'a lot of newspapers inside itself', since each supplement has a very specific graphic design. Souza (2011) argued that neither the publicity market in Rio Grande do Sul nor its readers are open to supplements that cannot be graphically distinguished from the body of the newspaper. Those who work in the newsroom 
also request this distinction. Still, the editor has not recognized that it is necessary for some patterns to encompass all the pages to guarantee the cohesion of the publication. He argues that the strategies are based on the different subscription models offered by the newspapers, in which readers can subscribe to Sunday issues, to working day issues only, or to Saturday/Sunday/Monday issues, for example. Daily supplements are more similar to the general pattern of the newspapers, while weekly issues aim at something different, with a layout closer to that of a magazine.

The theoretical framework also suggests distinctions between the style of the coverage of daily and weekly cultural supplements; differences that are related both to the periodicity of the supplements and the profile of the readers. The space devoted to culture in weekly supplements has more profound texts with a formative and critical characteristic. Segundo Caderno, a daily supplement, corresponds to some of the premises found in Gadini (2009) and Piza (2009), being related to supplements called 'varieties' or 'arts and shows'. According to our quantitative and qualitative research, there were numerous informative pieces, such as stories, notes, and briefs rather than news pieces, thus showing a lesser degree of depth in the themes. There is also a social column and television and movie schedules as pullouts of the supplement.

At the same time, the theme of the coverage also indicated that music and cinema were the most common subjects, generally connected to album releases and film premieres. These traits are in agreement with the one of the news values mentioned in the theoretical framework and found in the samples, which is timeliness. Another value that was very much present was proximity, which coincides with the preference $\mathrm{ZH}$ has of giving more prominence to content whose focus is the region of Porto Alegre. This characteristic could also be noticed in our interviews with these professionals. In the interview of reporter Marcelo Perrone (2011), he confirmed the preference of the newspaper for local themes. He also highlighted that this might be a distinctive characteristic of the coverage of the newspaper, where the reader can only find certain pieces of news in $\mathrm{ZH}$.

Taking into consideration Gadini's (2009) ideas, namely, that cultural journalism makes stories on the cultural sector and is influenced by this sector at the same time, we were able to identify the important connection with the schedule. During our observations, we witnessed the frequent arrival of publicity materials for the 
editorial staff, as well as the numerous e-mails received from the same sources. Books, CDs, magazines, DVDs, flyers, packages and boxes were found on the desks next to computers. Perrone (2011), on numerous occasions, commented on the issue that is created from the association with the schedule, from which the daily segment on culture cannot get away and must cover. In the interview with the editor of the segment, Ticiano Osório (2012), it was evident that, even though there is an initiative to stimulate creation rather than 'reproduction' of the material they receive, this is not an easy task and they are rarely successful at it. Osório (2012) also highlighted the positive side of this style of coverage, in which one can generally plan the story in advance. Osório (2012), however, recognizes that it might also not be very advantageous because of its being excessively conditioned to a pre-established scheme.

Many times during the interview the editor mentioned a series of factors that highlight the difficulty of dealing with the schedule, with issues ranging from the institutional level to particular factors of the staff, going through the news needs of each day that directly interfere in the decision-making process. Still, he stated that he looks for a balance between the topics in his approach to the segment, selecting stories that encompass different segments of the cultural sphere and giving preference to the production of their own pictures, since having a picture taken by one of their photographers makes it easier to compete for a spot on the cover of $\mathrm{ZH}$. However, the evidence found in our sample reveals a different perspective. When we looked into the source of the pictures, we found that most of them were publicity pictures, corresponding to practically half our sample (48\%). These are data that reflect the difficulty the department faces in trying to get beyond the cultural industry circuit.

The opinion of one of the newspapers photography editors, Jefferson Botega (2011), reveals a paradox. At the same time that there is no doubt about the importance of the role of the picture in the newspaper, he mentioned that the staff of photographers has been diminishing throughout the years at Zero Hora. Additionally, Botega (2011) revealed that many newspapers have not been investing in their own photographic coverage and, as a result they will not have different registers of a certain fact, from a particular point of view, since most pictures have the same origin and the material contributed by the newspaper itself is limited. In fact, a recurring approach to the layout we saw during our observations was that the composition of the pages had the picture as a starting 
point most of the times. In her interview, layout designer Lisiane Foletto (2011) pointed out: "the image is essential to thinking about the page". Corroborating this idea, Botega (2011) mentioned in his interview that "a good picture changes the layout of the page"; both of them revealing the importance of the image in the creative process.

On the one hand, we noticed, both in our observations and in our interview with Foletto (2011), that there is a certain routine in the layout designed oriented by the hierarchy of the supplement. Thus, this sequence was guided first by the level of complexity of each page and, second, by the urgency of the preparation of these pages in the production flow. On the other hand, it was possible to notice that there are some requirements that guide the graphic planning of the supplement, such as: characteristics of the pictures (motive, size, aesthetic quality); amount of text; editorial orientation, where, consequently, pages with the main story of the supplement will demand more time to be prepared; and conditions inherent to the daily production that decide which will be planned first. This structure, besides being in agreement with our theoretical background, reflects that pages which consume more production time and with pictures that offer interesting compositional possibilities tend to stimulate better layout solutions.

We must also point out that the fact of the stories having more time to be planned from an editorial perspective does not mean that those responsible for the layout also have this extra time, since they have to work with the layout of the newspaper on a daily basis. According to Souza (2011), this makes it more difficult to produce resources such as illustrations and infographics, because, depending on their complexity, they take more time to be created. The solution to this is that the editorial staff requests this material from the art department well in advance. According to the editor of the supplement Segundo Caderno, they attempt to plan the week in the editorial meetings on Fridays, at which they also discuss some graphic solutions to the stories they will cover. The layout designer is not present at this meeting due to the fact that Fridays are crucial to layout designers since they have to finish Saturday's issue and try to be done with Monday's issue as well.

In our interviews we also asked the professionals what the role that design played in the newspaper was and, regarding the conceptual perspective, all of them talked about what they consider essential. Souza (2011) emphasized the transitional phase print publications are currently going through due to new technologies. Softwares, he said, 
in addition to making a series of possibilities for pagination and image editing and processing feasible, also fomented the competitiveness between newspapers and other media, making the visual presentation of the newspaper even more important. Another aspect highlighted by Souza was the size of the art department staff in the newspaper. In addition to layout designers and photographers, there are more than fifty professionals "deciding on the best picture, or the best illustration, or the best infograph, choosing the best color, trying to find the best typography, designing a page once, twice" (SOUZA, 2011). This peculiarity reflects the relevance design has for the newspaper.

The layout designer mentioned the effort to offer readers a page graphically well planned to kindle their interest in reading and facilitate browsing through the topics. She also observed that it does not matter that the text is good if its presentation does not correspond to its quality. If the layout is not well planned, the reader probably will not focus on its content. Osório (2012) also discussed how important graphic experimentation and strong visual appeal are as part of the discursive strategy in cultural journalism. Thus, the editor reinforces the idea that the professional quality of a team is a factor that will influence in this aspect; not only from an editorial, but also from a graphic point of view. Corroborating this idea, Botega (2011) also seemed to believe that there are different types of professionals inside the picture department. Because of that he said that for Segundo Caderno stories the more suitable professional "[...] will be the one who is more poetic, the one who is more sensitive. It will be that guy that has a different eye that I will choose" (BOTEGA, 2011).

The path we undertook enabled us to notice some of the particularities that involved the graphic design and to understand many of the graphic solutions found in the supplement. According to what was indicated by the theoretical background, there are many aspects that condition the journalistic activity. The institutional and managerial situation of the news organization, production and printing deadlines, as well as human and material resource investments will influence what becomes news. Thus, the cycle of journalistic production is based on parameters that permeate the context of the newsroom and establish, in part, relationships between journalists, their sources, and the choices that derive from this conjuncture. 


\section{FINAL CONSIDERATIONS}

The inconsistency and unpredictability of the journalistic editorial content are transformed into continuity by establishing a graphic repertoire that is repeated in every new edition. Because of this, visual characteristics are crystallized in a graphic design that has the goal of expressing the personality of a certain publication. Even if we consider the parameters this project offers, the daily page composition must formally correspond to the singularity of the content of distinct issues. Thus, the election of certain compositional techniques must conform to the nature of the project and the demands of each content, so as to promote the desired connection to the readers.

In any visual composition, the act of making something that does not exist visible shows the complexity of a process that involves the designer in circumstances of selection and rejection, in which planning, intellectual inquiries and technical knowledge are fundamental. In the case of periodical publications this happens in a culture that is characteristic of this field, with its own values and practices. The routine presupposes tight deadlines both for the production of news pieces and the creation of layouts. We should also consider situations in which the deadline is even tighter; in these cases, not only are technical knowledge and the ability to manipulate elements essential to managing last-minute demands, but also agility and teamwork. Often the ideal solution will be simply doing the best one can in the time given.

Acting as a mediator between the cultural system and the public, cultural journalism interprets this system and provides models that influence peoples' actions and thoughts. Regarding the visual approach, the level of commitment that the graphic design assumes with the cultural coverage is high, so much so that the graphic design itself must be a cultural experience in action. Thus, the contact we had with those professionals and their work environment had the goal of bringing to our research the conditions of the creation of news pieces that were part of our object of study. More than comparing theory and practice, this approach derived from the idea that, in journalism, the work environment is very important and its conditions influence the final result in many aspects. We believe that research that proposes to study design should also contextualize its scope, since often an analytical view of a finished product might hide a series of processes that created it.

In this way, we were able to observe theoretical connections among the different areas used in our research, which we saw in 
the goals and correspondence between the criteria and values of journalism and the parameters that guide the practice of newspaper design. In the same way, there was, in many aspects, proximity between what the theory proposed and what was identified through the analysis. However, it was also possible to notice some questionable or dissonant matters. One of them refers to the readership. Even though the newspaper shows a certain concern in knowing its readers, this data does not seem to be shared with the professionals of the editorial staff, who feel relegated in this aspect. Perhaps the reason for this concern on the part of the newspaper is more to guide administrative and marketing strategies than the sharing of these statistics with the editorial staff. Another observation is that, in spite of the fact that the art editor of $\mathrm{ZH}$ affirms that its readers expect innovations in the newspaper, there are still traditional readers. An example of that is the frustrated attempt to remove the crossword puzzle from the segment, indicating that some habits are very strong. In this case, there is the question of whether this reader would indeed be open to visual audacities.

In the same way, this study identified contradictions regarding the coverage of the supplement Segundo Caderno and the elements found in its graphic design. We noticed the possibility of prior planning of the content because of its connection to the schedule. The theoretical support indicated that the visual layout of the daily cultural supplements was composed of illustrations and infographs, but this fact did not hold true in the samples used. However, $\mathrm{ZH}$ has a staff of professionals exclusively dedicated to develop these elements. In these cases, the main requirement for the production of this material was requesting them in advance from the art department of the newspaper.

Based on this perspective, there was another inconsistency regarding the source of pictures found in the samples. Bearing in mind the argument of the professionals regarding the focus of the coverage, which favors local events, would not this imply more pictures produced by $\mathrm{ZH}$ ? This does not mean that publicity pictures should not be used, a fact that would also go against other identified characteristics. What can be seen is that the production of pictures by photographers working directly for the newspaper could be more representative, not focusing only on the social column. $\mathrm{ZH}$ has a group of photographers to meet the demands of the editorial staff. Again, there is a visible need for the previous scheduling of a professional. Another factor that could demand more pictures taken by professionals of the newspaper 
would be the production of news pieces by the editorial staff. In our interviews, we could observe that $\mathrm{ZH}$ is willing to provide extra resources to cover stories. The issue here was also planning.

Finally, we believe that it is important to stress the effort made to build a methodology that covered the proposed goal, which, to a certain extent, reflects the difficulty that is present in the study of a graphic object in the field of communication studies. A lot of this can be due to the complexity and, to a certain degree, to the subjectivity present in that trade, in terms of analysis. Unlike other methodological perspectives, the field of design does not offer clear-cut pathways and pre-established research methods. Thus, evaluation procedures were constructed, aiming to make use of the best possible options in these conditions.

We understand that this study aimed to bring the perspective of communication studies to the field of design, bearing in mind the proximity of the two fields, since we realized that there was a limited body of research dedicated to the investigation of the visual phenomenon in the sphere of journalism. This movement highlighted not only how much the praxis of design does indeed reflect a specific work culture and the values of a certain field, but it also reflects the relevance of the role of design as it is applied in newspapers.

\section{NOTES}

1 From the thesis $\mathrm{O}$ design editorial da cultura: um estudo do projeto gráfico do Segundo Caderno do jornal Zero Hora presented in 2012 in the Communication and Information Graduate Program from Universidade Federal do Rio Grande do Sul (PPGCOM/UFRGS).

2 See ranking "Maiores Jornais do Brasil" from the Associação Nacional de Jornais which measures the circulation of the country's periodicals. Available at: http://www.anj.org.br/a-industria-jornalistica/jornaisno-brasil/maiores-jornais-do-brasil.

3 Among the newspapers that changed their designs are: $\mathrm{O}$ Estado de S. Paulo, Folha de São Paulo, Diário de São Paulo, A Tribuna (from Santos), O Globo, Jornal da Tarde, Extra, and Zero Hora. According to the Instituto Verificador de Circulação [Circulation Verifying Institute] (IVC), after the decrease in circulation from 2008 to 2009, there was an increase in the average circulation in the year 2010 and in the first semester of 2011 . In 2010 the average increase was 1.5\% in 
relation to 2009. In the first semester of 2011 the increase was $4.2 \%$ in relation to the same period in 2010 .

4 Sandra Sanches, executive director of a sector of O Globo in an interview given to Jornal Meio \& Mensagem. Zero Hora projects its specific content to attract young people, since $53 \%$ of its readers are less than 40 years-old. Available at http://www.opovo.com.br/app/ opovo/tendencias/2011/03/11/noticiatendenciajornal,2111953/ vida-longa-aos-jornais.shtml. Accessed on July 17, 2011.

5 The company's website says there is an increase in the average circulation of ZH: 176,412 copies/day in 2007, 179,934 in 2008, 183,521 in 2009 , and 184,663 in 2010 . From January to August 2011 the average circulation was of 187,978 copies, an increase of $1.8 \%$ in comparison to the same period the previous year, when the average was 184,655 copies. Accessed on July 17, 2011.

6 http://gruporbs.clicrbs.com.br/blog/2011/09/23/zero-hora-baterecorde-com-circulacao-de-mais-de-190-mil-exemplares-em-agosto/.

7 The media kit provided to the researcher by Zero Hora has data on the newspaper market in the state of Rio Grande do Sul. This survey was commissioned by $\mathrm{ZH}$ to the survey institute Ipsos Marplan EGM, Porto Alegre, in 2010.

8 The scope of the survey was 2,778,000 people in the metropolitan area of Porto Alegre from January to December 2010 and indicated that 775,000 people read the newspaper Zero Hora.

REFERENCES

ARNHEIM, R. Arte e percepção visual. São Paulo: Pioneira, 2005.

BOTEGA, Jefferson. Depoimento. [12 de dezembro de 2011] Porto Alegre: Zero Hora. Interview granted to Patricia Lopes Damasceno.

DEJAVITE, F. O INFOtenimento nas páginas do jornal impresso: análise do O Estado de S.Paulo. In: XXXI Congresso Brasileiro de Ciências da Comunicação, Natal, RN 2008. Available at http://intercom.org.br/papers/ nacionais/2008/resumos/R3-1809-1.pdf. Accessed on: September 12, 2009.

DONDIS, D. A. Sintaxe da Linguagem Visual. São Paulo: Martins Fontes, 2007. 
FOLETTO, Lisiane. Depoimento. [5 de dezembro de 2011] Porto Alegre: Zero Hora. Interview granted to Patricia Lopes Damasceno.

FONSECA, V. S. Indústria de notícias: capitalismo e novas tecnologias no jornalismo contemporâneo. Porto Alegre: Editora da UFRGS, 2008.

FROST, Chris. Designing for newspapers and magazines. New York: Routledge, 2003.

GÄDE, R. Diseño de periódicos. Sistema y método. Barcelona: Gustavo Gili, 2002.

GADINI, S. Interesses Cruzados: a produção da cultura no jornalismo brasileiro. São Paulo: Paulus, 2009.

GARCIA, M. Contemporary newspaper design. Englewood Fields: Prentice-Hall, 1987. $2^{\circ}$ edition.

GIL, A. C. Métodos e técnicas de pesquisa social. São Paulo: Atlas, 2007.

GOLIN, C.; CARDOSO, E.. Jornalismo e representação do sistema de produção cultural: mediação e visibilidade. In: BOLAÑO, C.; GOLIN, C.; BRITTOS, V. Economia da arte e da cultura. $1^{\text {a }}$ ed. São Paulo: Itaú Cultural, 2010, p. 184-203.

GOMES FILHO, J. Gestalt do Objeto: sistema de leitura visual da forma. São Paulo: Escrituras Editora, 2004.

GruszYNSKI, A. C. A forma que (in)forma: o projeto gráfico do jornal impresso na contemporaneidade. In: Anais do XXXIV Congresso Brasileiro de Ciências da Comunicação. Recife: Intercom, 2011. Available at: <http://www.intercom.org.br/papers/nacionais/2011/ index.htm> Accessed on: December 10, 2011.

O papel do design gráfico no estabelecimento de contratos de leitura de jornais impressos: um estudo sobre a reforma gráfica de 2010 da Folha de S. Paulo. Estudos em Comunicação, Covilhã, Lab Com, v. 1, p. 85-106, 2012. Available at: <http://www. ec.ubi.pt/ec/12/pdf/EC12-2012Dez-5.pdf> Accessed on: February 20, 2013.

LAREQUI, J. C. El diseño periodístico en prensa diária. Madrid: Casa Editorial, 1994.

LOCKWOOD, R. News by design. A survival guide for newspapers. Colorado: Quark Press, 1992.

LUPTON, E.; PHILLIPS, J. Novos fundamentos do design. São Paulo: Cosac Naify, 2008. 
OSÓRIO, Ticiano. Depoimento. [5 de janeiro de 2012] Porto Alegre: Zero Hora. Interview granted to Patricia Lopes Damasceno.

PERRONE, Marcelo. Depoimento. [12 de dezembro de 2011] Porto Alegre: Zero Hora. Interview granted to Patricia Lopes Damasceno.

PIZA, D. Jornalismo cultural. São Paulo: Contexto, 2009.

SOUZA, Luiz Adolfo Lino. Depoimento. [12 de dezembro de 2011] Porto Alegre: Zero Hora. Interview granted to Patricia Lopes Damasceno.

WOLF, M. Teorias da Comunicação. Portugal: Editorial Presença, 1995. ZAPPATERRA, Y. Art direction + editorial design. USA: Abrahams Studio, 2007.

Patrícia Lopes Damasceno MA. in Communication and Information from Universidade Federal do Rio Grande do Sul (UFRCS). Professor of Graphic Design at Universidade Federal de Pelotas (UFPel). E-mail: pldamasceno@gmail.com

Ana Gruszynski Ph.D. in Social Communication from Pontifícia Universidade Católica do Rio Grande do Sul (PUCRS). Professor in the Communication and Information Graduate Program of Universidade Federal do Rio Grande do Sul (PPGCOM/UFRGS). Researcher of the Conselho Nacional de Desenvolvimento Científico e Tecnológico (CNPq). E-mail: anagru@gmail.com 